ISSN: 2637-7659

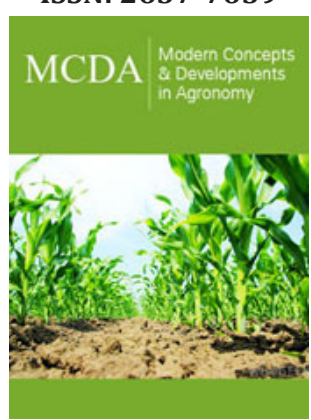

*Corresponding author: Niknam V, Department of Plant Biology, School of Biology, College of Science, Tehran, Iran

Submission: 诲 June 20, 2019

Published: 㭗July 01, 2019

Volume 4 - Issue 5

How to cite this article: Heydari $\mathrm{H}$, Shaki F, Niknam V, Ebrahimzadeh Maboud H. Different Effects of Penconazole on Enzymatic and Non-enzymatic Antioxidants of Sesame (Sesamum indicum L.) Under Salinity. Mod Concep Dev Agrono.4(5). MCDA.000596.2019. DOI: 10.31031/MCDA.2019.04.000596

Copyright@ Niknam V, This article is distributed under the terms of the Creative Commons Attribution 4.0 International License, which permits unrestricted use and redistribution provided that the original author and source are credited.

\section{Different Effects of Penconazole on Enzymatic and Non-enzymatic Antioxidants of Sesame (Sesamum indicum L.) Under Salinity}

\author{
Heydari H, Shaki F, Niknam V* and Ebrahimzadeh Maboud H
}

Department of Plant Biology, Iran

\begin{abstract}
Salinization of soil is recognized as one of the most pressing environmental challenges to resolve for the next century. The ability to respond to environmental stimuli is among the most fundamental processes that enable plants to survive. Penconazole (PEN), a triazole group of fungicide, which has both fungicidal and plant growth regulator properties, protects plants from several types of abiotic stresses. The purpose of this work is to assess the effect of sodium chloride $(0,50,100$, and $200 \mathrm{mM})$ and PEN $(15 \mathrm{mg} / \mathrm{L})$ on some biochemical responses of sesame. Results revealed that some growth parameters decreased under salinity however, compatible solutes, $\mathrm{H}_{2} \mathrm{O}_{2}$ and Malondialdehyde (MDA) levels, flavonoid content, and PPO enzyme activity increased. PEN application had a positive effect on growth parameters, proline and $\mathrm{H}_{2} \mathrm{O}_{2}$ contents, SOD, CAT and POX enzyme activities, but decreased MDA, carbohydrate, flavonoid and anthocyanin contents, as well as PPO activity. According to our results, PEN changed physiological and biochemical parameters, and therefore, due to its low price and availability is suggested for reduction of the negative effects of salinity in sesame.
\end{abstract}

Keywords: Penconazole; Salt stress; Sesamum indicum L.; Tolerance

\section{Introduction}

Climate change is one of the major challenges of our time and the socio-economic consequences are alarming. It is predicted that global climate change may alter environmental parameters such as rainfall distribution which in turn may alter the salinity of soils in many areas [1]. Salinity is an environmental factor limiting crop production and soil fertility in arid and semi-arid regions [2,3]. Like most of crops, yield of sesame decreases under salinity [4]. Sesame has been cultivated for its oil and is capable of producing profitable crops in saline conditions [4]. However, its productivity decreases as the salinity level increases [5]. Under saline conditions, plants have adopted mechanisms to protect themselves by some strategies such as the accumulation of compatible solutes, the production of reactive oxygen species, and accumulation of important secondary metabolites [6]. The accumulation of compatible solutes such as proline and carbohydrate, which is in cytosole, is considered as a basic strategy for the protection of plants in response to stress conditions [7,8]. In addition, high carbohydrate levels caused the maintenance of the protein structures in environmental stresses [9]. Under stress conditions, a specific level of ROS is required to induce antioxidative protection in cells [10]. Various antioxidative enzymes are involved in detoxification of ROS in stress conditions. Plants can also synthesize some low molecular weight components such as flavonoids and anthocyanins under saline conditions [11]. These compounds are some non-enzymatic antioxidants which scavenge oxidative free radicals [12]. The ability of flavonoids to act as antioxidants depends on the reduction potentials of their radicals [13]. Further, anthocyanins are kinds of pigments derived from flavonoids, which accumulate in tissues under the influence of environmental stimuli [13]. Penconazole (PEN) as a triazolic group of fungicide, which act as signal transducers and causes various responses in plants [14]. This compound could cause increase in antioxidant potential, reduction in ROS damage and induction of growth in roots [10]. These features make PEN an ideal chemical to increase stress tolerance in plants. To the best of our knowledge, there is a little information available so far about the effect of PEN on plant species and there was no information in Sesamum 
indicum $\mathrm{L}$. Therefore, the aim of the present study was to investigate the impact of PEN on some physiological parameters in Sesamum indicum L. Our results might provide a basis to enhance the growth and productivity of sesame in salt-affected areas.

\section{Material and Methods}

\section{Plant cultivation and treatments}

Seeds from sesame (Ultan cultivar) were sown in Tref peat in a greenhouse. Seedlings were thinned to four per plastic pot. Then seedlings were treated with different $\mathrm{NaCl}$ concentration $(0,50$, $100,200 \mathrm{mM}$ ) in Hoagland's solution [15], with or without fungicide penconazole (15 $\mathrm{mg} \mathrm{L}^{-1}$ ) for 21 days. The PEN was sprayed once a week on plants. Plants were collected after 21 days and the leaves were sampled and stored at $-70^{\circ} \mathrm{C}$ for biochemical analysis.

\section{Growth parameters}

Plants were evaluated 21 days after the start of treatments in terms of dry weight (DW). Relative water content (RWC) in leaf tissues was quantified by method of Wheatherley [16].

\section{Proline content determination}

Leaf samples $(0.5 \mathrm{~g})$ were homogenized in $5 \mathrm{ml}$ of sulphosalicylic acid (3\%) for determination of proline content [17]. Then, samples were set aside to allow separation of the organic and aqueous phases. The absorbance was read at $520 \mathrm{~nm}$ using spectrophotometer. Proline concentration was determined from a standard curve.

\section{Carbohydrate content determination}

Carbohydrate content was determined according to the method of Dubois [18]. Dry leaves $(0.1 \mathrm{~g})$ were extracted using ethanol: distilled water $(8: 2 ; \mathrm{v} / \mathrm{v})$. Then, sulphuric acid $(2.5 \mathrm{ml})$ and phenol solution $(0.5 \mathrm{ml})$ were added to the samples, and the absorbance was recorded at $485 \mathrm{~nm}$.

\section{Malondialdehyde determination}

Malondialdehyde (MDA) was determined according to Heath and Packer [19]. Plant tissues (0.2 g) were homogenized in $2 \mathrm{ml}$ of trichloroacetic acid (TCA). TCA (4ml) containing thiobarbituric acid (TBA) $(0.5 \%)$ was added to the supernatant. After that the absorbance of the mixture was evaluated at 532 and $600 \mathrm{~nm}$. The value for non-specific absorption at $600 \mathrm{~nm}$ was then subtracted from that of $532 \mathrm{~nm}$.

\section{$\mathrm{H}_{2} \mathrm{O}_{2}$ Content determination}

Leaves $(0.5 \mathrm{~g})$ were extracted in TCA $(1 \mathrm{ml})$. A $0.5 \mathrm{ml}$ of the extract added to $10 \mathrm{mM}$ potassium phosphate $(0.5 \mathrm{ml})$ and potassium iodide (KI) (1ml) [20]. The absorbance was read at 390nm.

\section{Enzyme's activity determination}

Leaf tissues $(1 \mathrm{~g})$ were extracted in Tris- $\mathrm{HCl}(1 \mathrm{M})$. The Tris$\mathrm{HCl}$ buffer contained dithiotheritol $(5 \mathrm{mM}), \mathrm{NaCl}(0.5 \mathrm{mM})$, and ethylenediaminetetraacetic acid (EDTA) (5mM). The mixture was kept at $-70{ }^{\circ} \mathrm{C}$ and used for determination of protein and enzyme assays. Proteins were determined according to Bradford [21].
Estimation of Superoxide dismutase activity was performed using the methods of Giannopolitis and Ries [22]. The reaction mixture contained riboflavin $(75 \mu \mathrm{M})$, L-methionine $(13 \mathrm{mM})$, sodium phosphate $(50 \mathrm{mM})$, EDTA $(0.1 \mathrm{mM})$, NBT $(75 \mu \mathrm{M})$, and protein extract from plants $(0.1 \mathrm{ml})$. The mixture was irradiated for $20 \mathrm{~min}$ and the final absorbance was read at 560nm against the nonirradiated blank. Catalase activity was measured in one minute according to methods of Aebi [23]. The reaction mixture was made up of potassium phosphate buffer $(0.625 \mathrm{ml}), \mathrm{H}_{2} \mathrm{O}_{2}(75 \mu \mathrm{l})$, and protein extract $(10 \mu \mathrm{l})$. Peroxidase activity determined according to the methods of Abeles and Biles [24]. The increase in absorbance was recorded at $530 \mathrm{~nm}$ for $1 \mathrm{~min}$. The enzyme activity was defined as $l \mu \mathrm{M}$ of benzidine oxidized per min per mg protein. Polyphenol oxidase activity determined according to the methods of Raymond et al. [25]. The increase in absorbance was recorded at $430 \mathrm{~nm}$ for $1 \mathrm{~min}$. The PPO activity was defined as $1 \mu \mathrm{M}$ of pyrogallol oxidized per min per mg protein.

\section{Flavonoid content determination}

Flavonoid content was determined using the method of Pourmorad et al. [26]. Leaves (0.1g) were extracted in $80 \%$ methanol $(2 \mathrm{ml})$. Extracts $(0.5 \mathrm{ml})$ were mixed with methanol $(2 \mathrm{ml})$, aluminum chloride $(0.1 \mathrm{ml})$, potassium acetate $(0.1 \mathrm{ml})$, and were kept at room temperature for $30 \mathrm{~min}$. The absorbance was recorded at $415 \mathrm{~nm}$.

\section{Anthocyanin content determination}

Leaf tissues $(0.1 \mathrm{~g})$ were homogenized in methanol $(10 \mathrm{ml})$ according to the methods of Wagner [27]. The absorbance of the solution for the samples was read at $550 \mathrm{~nm}$.

\section{Statistical Analysis}

The experiment was performed with three replications, and each data point was the mean of three replicates. Statistical analysis was calculated with SPSS (version 19). Tests for significant differences between samples were conducted using analysis of variance with Duncan's multiple range tests at the 0.05 level of confidence.

\section{Result}

Growth parameters were followed by measuring FW, DW, plants height, and RWC (Table 1). Under salinity, FW and DW significantly decreased in plants with the increasing $\mathrm{NaCl}$ concentrations (Table 1). PEN increased FW and DW in salt-stressed and unstressed plants. However, FW decreased in $200 \mathrm{mM} \mathrm{NaCl}$ treated plants after PEN application. Salinity also reduced plant length in 100 and $200 \mathrm{mM} \mathrm{NaCl}$ treated plants. PEN application increased plant length in controls and plants under $200 \mathrm{mM} \mathrm{NaCl}$ treatment. Further, RWC decreased more than 2 -fold in $200 \mathrm{mM} \mathrm{NaCl}$ treated plants when compared to controls. However, PEN application increased RWC in plants treated with 50 and $200 \mathrm{mM} \mathrm{NaCl}$. Proline accumulation decreased in plants subjected to $100 \mathrm{mM} \mathrm{NaCl}$ treatment (Figure 1). However proline content increased in $200 \mathrm{mM}$ $\mathrm{NaCl}$ treated plants. This increase was more than 2-fold compered 
to controls. PEN treatment to plants decreased proline content in untreated and $50 \mathrm{mM} \mathrm{NaCl}$ treated plants while, the amount of this compound increased in $200 \mathrm{mM} \mathrm{NaCl}$ treated plants with PEN application. Carbohydrate concentration increased with increasing concentrations of $\mathrm{NaCl}$ (Figure 1).

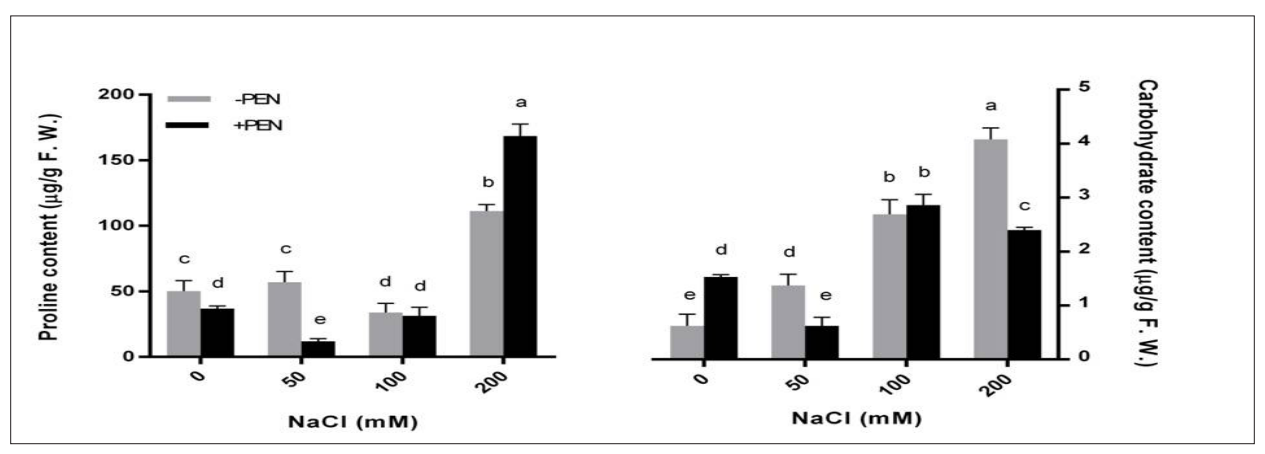

Figure 1: Effects of salinity and exogenous PEN on content of proline and carbohydrate in sesame plants at 21 days after the start of treatments. The groups are -PEN (plants with no penconazole treatment) and + PEN (plants sprayed with $15 \mathrm{mgL}^{-1}$ penconazole once a week). Columns indicate mean $\pm \mathrm{SE}$.

This increase was more than 6 -fold in $200 \mathrm{mM} \mathrm{NaCl}$ treated plants when compared to controls. PEN application increased carbohydrate content in unstressed plants. However, PEN reduced carbohydrate content in 50 and $200 \mathrm{mM} \mathrm{NaCl}$ treated plants. For determination of ROS scavenging capacity, $\mathrm{H}_{2} \mathrm{O}_{2}$ levels of sesame plants were estimated. $\mathrm{H}_{2} \mathrm{O}_{2}$ content decreased in plants under 50 and $100 \mathrm{mM} \mathrm{NaCl}$ treatments while, its content increased in plants under $200 \mathrm{mM} \mathrm{NaCl}$ treatment (Figure 2). PEN application decreased $\mathrm{H}_{2} \mathrm{O}_{2}$ production in controls and $50 \mathrm{mM} \mathrm{NaCl}$ treated plants. However, PEN increased $\mathrm{H}_{2} \mathrm{O}_{2}$ contents in plants under 100 and $200 \mathrm{mM} \mathrm{NaCl}$ treatments. Salt stress decreased MDA production in sesame under 50 and $100 \mathrm{mM} \mathrm{NaCl}$ treatments, while increased MDA content in $200 \mathrm{mM} \mathrm{NaCl}$ treated plants (Figure 2). This increase was about 2-fold compered to controls. However, PEN treatment decreased MDA content in both salt-stressed and unstressed plants, except in plants under $100 \mathrm{mM} \mathrm{NaCl}$ treatment. The effect of PEN was most pronounced in $200 \mathrm{mM} \mathrm{NaCl}$ treated plants.
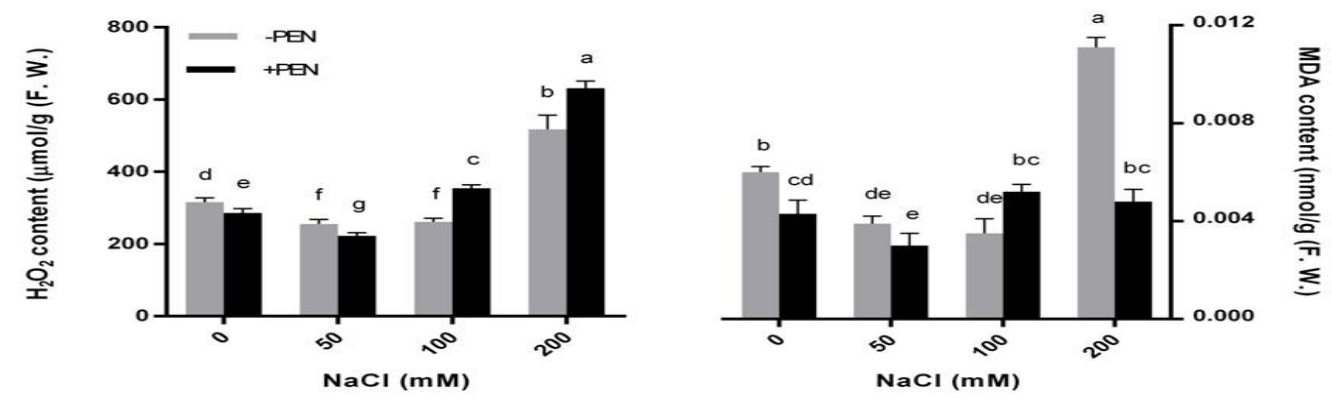

Figure 2: Effects of salinity and exogenous PEN on content of malondialdehyde (MDA) and hydrogen peroxide $\left(\mathrm{H}_{2} \mathrm{O}_{2}\right)$ in sesame at 21 days after the start of treatments. The groups are -PEN (plants with no penconazole treatment) and +PEN (plants sprayed with $15 \mathrm{mgL}^{-1}$ penconazole once a week). Columns indicate mean $\pm \mathrm{SE}$.

The differences in antioxidant enzymes (SOD, CAT, POX, and PPO) activities are depicted in Table 2. Salt stress decreased CAT, SOD and POX activities, while increased PPO activity in NaCl treated plants. Exogenous application of PEN to salt-stressed plants caused a higher induction of CAT, SOD, and POX activities when compared to control plants. However, PEN decreased PPO activity in $200 \mathrm{mM}$ $\mathrm{NaCl}$ treated plants. In this study, the higher induction of enzyme activity was related to PPO in PEN-treated plants under $100 \mathrm{mM}$ $\mathrm{NaCl}$ treatment. According to the data obtained from this study, flavonoid production decreased in 50 and $100 \mathrm{mM} \mathrm{NaCl}$ treated plants (Figure 3). However, its content increased in plants under
$200 \mathrm{mM} \mathrm{NaCl}$ treatment. PEN application increased flavonoid content in unstressed plants while, decreased its content in all salt-stressed plants. This reduction was most pronounced in $200 \mathrm{mM} \mathrm{NaCl}$ treated plants. Salt stress also decreased anthocyanin content in plants under 50 and $100 \mathrm{mM} \mathrm{NaCl}$ treatments (Figure 3). PEN application decreased anthocyanin content in untreated and $200 \mathrm{mM} \mathrm{NaCl}$ treated plants. PCA analysis revealed that, principal component 1 (F1) described 39.09\% and principal component 2 (F2) described $19.99 \%$ of the total variation (Figure 4) with a cumulative percentage of 59.08\%. PPO and RWC were grouped with positive loading on the right upper side of the biplot. Further, 
FW, DW, SOD, POX, CAT, and height were observed on the right lower side, and MDA, $\mathrm{H}_{2} \mathrm{O}_{2}$, flavonoid, anthocyanin, and proline were grouped on the left lower side of the biplot. Carbohydrate was the only parameter on the left upper side of the biplot. These parameters had a positive correlation among themselves with vectors in the same directions.

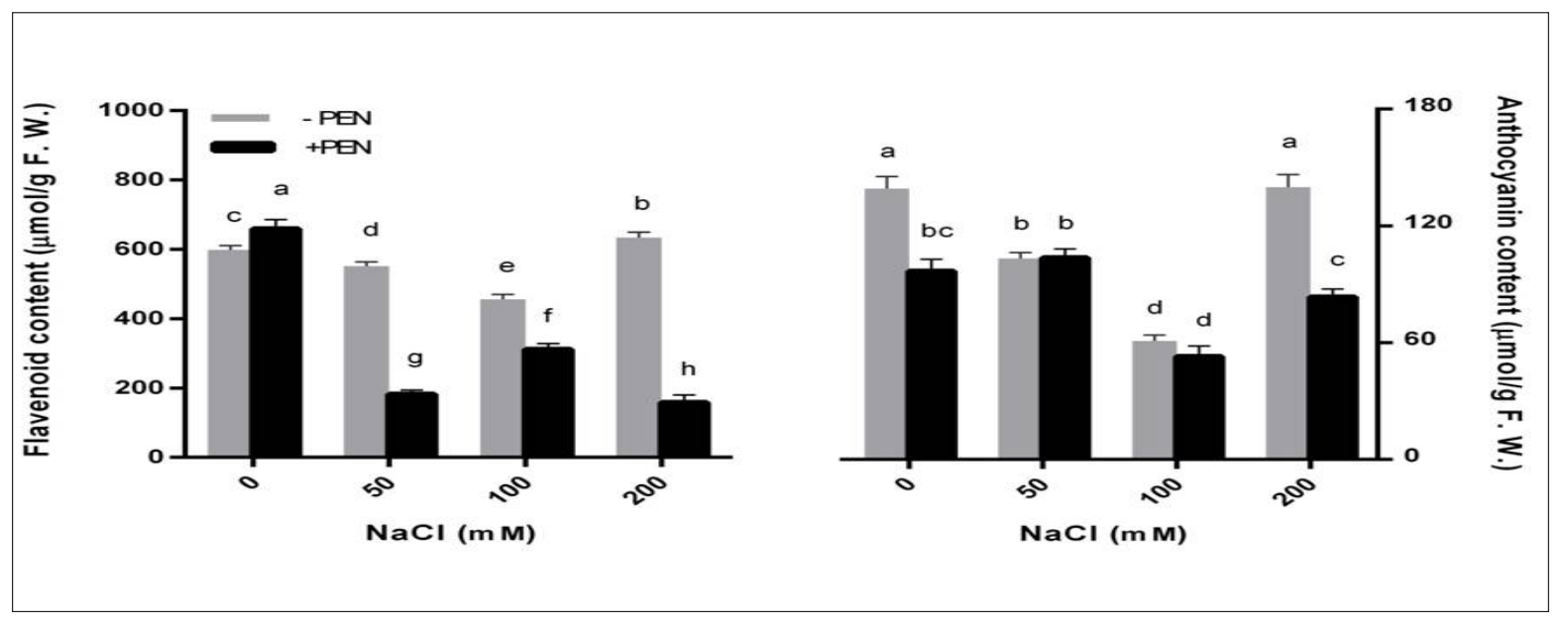

Figure 3: Effects of salinity and exogenous PEN on content of flavonoid and anthocyanin in sesame at 21 days after the start of treatments. The groups are -PEN (plants with no penconazole treatment) and + PEN (plants sprayed with $15 \mathrm{mgL}^{-1}$ penconazole once a week). Columns indicate mean $\pm \mathrm{SE}$.

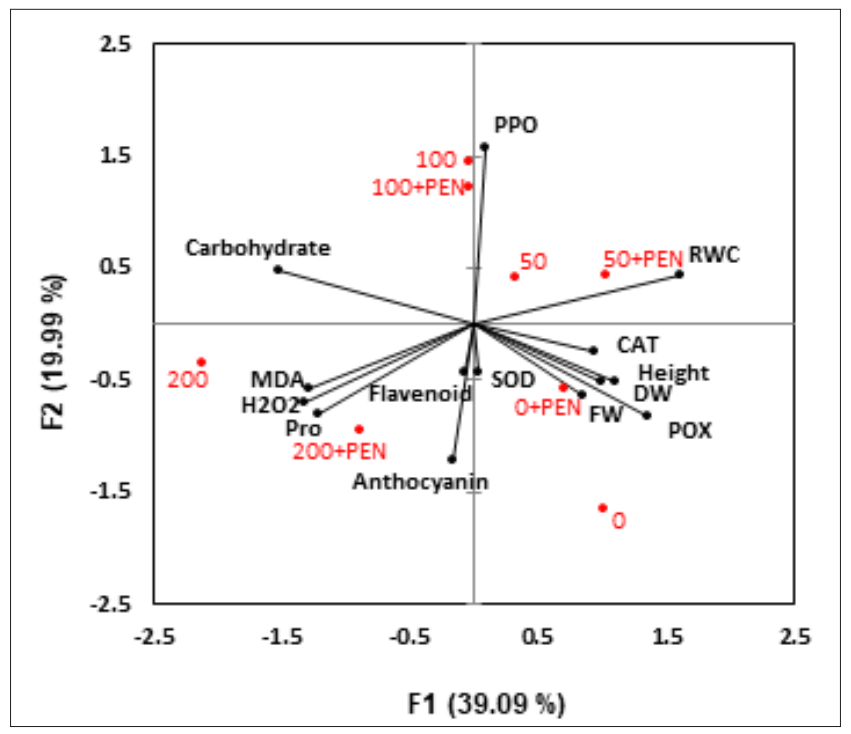

Figure 4: Loading plots of principal components 1 and 2 of the PCA. Results obtained from biochemical data of sesame plants subjected to salinity and exogenous PEN.

Notes: MDA: malondialdehyde, SOD: superoxide dismutase, PPO: polyphenol oxidase, POX: peroxidase, Pro: proline, CAT: catalase, FW: fresh weigh, DW: dry weigh.

\section{Discussion}

The present study, for the first time, reports the positive effects of PEN on salt tolerance of sesame. In this experiment, growth parameters were inhibited under $\mathrm{NaCl}$ concentrations. Reduction of plant growth under salinity have been previously reported by other researchers $[6,10,28]$. Exogenous application of PEN prevented, to some extent, the negative effects of stress, especially in $200 \mathrm{mM} \mathrm{NaCl}$ treated plants, and allowed increased plant growth (Table 1). It was found that PEN had most effect on tolerance at severe salt stress. Our results are in agreement with other studies which reported promoting effect of triazoles on cytokinin content, cell division, and therefore growth enhancement in different plant species [29]. Accumulation of proline under stress conditions in many plant species has been correlated with stress tolerance [14,30]. Proline generally accumulates in response to environmental stresses in cytosol (Kishor et al. 2005). This compound can play a significant role in maintaining osmotic adjustment [31]. In this study, proline content was increased dramatically under severe $\mathrm{NaCl}$ concentration with and without PEN application. It was observed that ABA treatment caused an increase in the level of proline in water-stressed sunflower plants [32]. 
Table 1: Effects of $\mathrm{NaCl}$ and penconazole on growth parameters at 21 days after the start of treatments in sesame.

\begin{tabular}{|c|c|c|c|c|c|}
\hline \multicolumn{2}{|c|}{ Treatments } & \multicolumn{4}{|c|}{ Parameters } \\
\hline Penconazole & $\mathrm{NaCl}(\mathrm{mM})$ & FW (g) & DW (g) & Height (cm) & RWC (\%) \\
\hline \multirow{4}{*}{-PEN } & 0 & $3.27 \pm 0.43 b$ & $0.29 \pm 0.01 b c$ & $38.0 \pm 1.0 \mathrm{~b}$ & $53.03 \pm 0.46 b$ \\
\hline & 50 & $1.46 \pm 0.26 f$ & $0.32 \pm 0.36 b$ & $40.5 \pm 3.5 b$ & $53.72 \pm 1.96 b$ \\
\hline & 100 & $1.95 \pm 0.02 \mathrm{~d}$ & $0.20 \pm 0.04 \mathrm{~d}$ & $31.0 \pm 1.0 \mathrm{c}$ & $50.00 \pm 5.22 b$ \\
\hline & 200 & $1.70 \pm 0.14 \mathrm{e}$ & $0.12 \pm 0.01 \mathrm{e}$ & $28.5 \pm 2.5 \mathrm{~d}$ & $23.52 \pm 1.08 \mathrm{~d}$ \\
\hline \multirow{4}{*}{$+\mathrm{PEN}$} & 0 & $3.53 \pm 0.08 \mathrm{a}$ & $0.48 \pm 0.02 \mathrm{a}$ & $33.5 \pm 3.5 c$ & $51.65 \pm 0.99 \mathrm{~b}$ \\
\hline & 50 & $1.77 \pm 0.10 \mathrm{e}$ & $0.31 \pm 0.03 b$ & $39.0 \pm 3.0 \mathrm{~b}$ & $56.47 \pm 1.29 a$ \\
\hline & 100 & $2.41 \pm 0.19 c$ & $0.24 \pm 0.01 \mathrm{c}$ & $32.0 \pm 1.0 \mathrm{c}$ & $51.53 \pm 5.25 b$ \\
\hline & 200 & $1.51 \pm 0.11 \mathrm{f}$ & $0.31 \pm 0.17 \mathrm{~b}$ & $38.0 \pm 1.0 \mathrm{~b}$ & $37.87 \pm 3.98 \mathrm{c}$ \\
\hline
\end{tabular}

In addition, triazolic compounds induced a transient rise in the ABA levels [9]. Hence, it seems that increased ABA content due to the triazole treatment might be the main reason for the increased proline content in PEN-treated sesame plants. Carbohydrate accumulation has been observed in other plant species in saline conditions [33,34]. The high carbohydrate concentrations contributed to the prevention of oxidative damage and the maintenance of the structure of proteins in stress conditions. In our experiment, PEN application reduced the carbohydrate content in salt-treated sesame plants. Reduction in the level of carbohydrate in PEN-treated plants indicates the stress amelioration role of PEN that could be responsible for maintenance of plant growth in stress conditions. In the present study, MDA (a product of membrane lipid peroxidation) content increased dramatically under severe salt concentration. However, this oxidative damage was ameliorated by application of exogenous PEN. Further, the study related to $\mathrm{H}_{2} \mathrm{O}_{2}$ content indicated an increase under severe $\mathrm{NaCl}$ treatment. Exogenous PEN caused an increase in $\mathrm{H}_{2} \mathrm{O}_{2}$ level. Our results are in agreement with findings in safflower plants [14] in which applied
PEN had positive effects on plant growth under stress conditions. Plants respond to stress by increasing antioxidant capacity of cells to restore the cellular equilibrium [35]. According to our data, activity of SOD, CAT, and POX as ROS scavengers in sesame decreased after exposure to saline conditions. Similarly, reduction in activity of these enzymes was reported in salt-stressed cowpea [36], tomato [37], liquorice [38], and maize [39] plants. In addition, PEN application increased SOD, CAT, and POX enzyme activities in sesame. Our results are in agreement with other findings in different plant species $[10,29,35]$ in which triazolic compounds had positive effects on antioxidant enzyme activities under stress conditions. PEN-induced antioxidant enzyme activities may be a mechanism to increase salt resistance in sesame plants. It is likely that regulation of CAT and POX activity can reduce excess accumulation of $\mathrm{H}_{2} \mathrm{O}_{2}$, and therefore, some essential signaling functions could occur in cells. PPO is also an oxidative enzyme and has a significant role in oxidation of phenolic compounds. PPO activity remarkably increased under salt stress in sesame plants (Table 2).

Table 2: Effect of $\mathrm{NaCl}$ and penconazole on enzymes activities at 21 days after the start of treatments in sesame.

\begin{tabular}{|c|c|c|c|c|c|}
\hline \multicolumn{2}{|c|}{ Treatments } & \multicolumn{4}{c|}{ Antioxidant Enzymes Activity [U mg ${ }^{-1}$ (protein)] } \\
\hline Penconazole & NaCl (mM) & SOD & CAT & POX & PPO \\
\hline -PEN & 0 & $0.110 \pm 0.01 \mathrm{~b}$ & $0.031 \pm 0.01 \mathrm{a}$ & $0.031 \pm 0.00 \mathrm{a}$ & $0.041 \pm 0.00 \mathrm{~d}$ \\
\hline & 50 & $0.040 \pm 0.00 \mathrm{e}$ & $0.011 \pm 0.00 \mathrm{c}$ & $0.010 \pm 0.00 \mathrm{c}$ & $0.131 \pm 0.00 \mathrm{~b}$ \\
\hline & 100 & $0.080 \pm 0.01 \mathrm{~d}$ & $0.021 \pm 0.00 \mathrm{~b}$ & $0.007 \pm 0.00 \mathrm{~d}$ & $0.182 \pm 0.00 \mathrm{a}$ \\
\hline & 200 & $0.050 \pm 0.00 \mathrm{e}$ & $0.010 \pm 0.00 \mathrm{c}$ & $0.003 \pm 0.00 \mathrm{e}$ & $0.050 \pm 0.00 \mathrm{~d}$ \\
\hline & 0 & $0.040 \pm 0.00 \mathrm{e}$ & $0.012 \pm 0.00 \mathrm{c}$ & $0.020 \pm 0.00 \mathrm{~b}$ & $0.141 \pm 0.01 \mathrm{~b}$ \\
\hline & 50 & $0.077 \pm 0.03 \mathrm{~d}$ & $0.020 \pm 0.01 \mathrm{~b}$ & $0.021 \pm 0.00 \mathrm{~b}$ & $0.190 \pm 0.02 \mathrm{a}$ \\
\hline & 100 & $0.095 \pm 0.00 \mathrm{c}$ & $0.019 \pm 0.00 \mathrm{~b}$ & $0.011 \pm 0.00 \mathrm{c}$ & $0.011 \pm 0.00 \mathrm{e}$ \\
\hline
\end{tabular}

Notes: The groups are -PEN (plants with no penconazole treatment), +PEN (plants sprayed with $15 \mathrm{mgL}^{-1}$ penconazole once a week). Data are the means \pm SE.

SOD: superoxide dismutase, POX: peroxidase, PPO: polyphenol oxidase CAT: catalase 
Increased PPO activity might reduce the phenolic compounds thereby protecting the content of Indole-3-acetic acid (IAA) and this can enhance cell wall growth [10]. These results are in agreement with the results of drought-stressed $V$. unguiculata after triazole compound application [40] and indicate that plant response to salt stress might be PEN dependent. The same was also observed in induction of non-enzymatic antioxidant compounds in plants. Flavonoids protect plants against various stresses and play an important role in the interaction between the plants and environment [41]. In this study, flavonoid content increased only under severe salt concentration. Our results are in agreement with the results on salt-stressed plants of rice [13]. PEN application in salt-treated sesame plants had a lower induction of flavonoid when compared to controls. Thus, it can be assumed that flavonoid reduction in PEN-treated plants in this work might probably be due to decreasing the phenolic compounds. In addition, anthocyanin content decreased in some of the salttreated plants and PEN application reduced its content especially, under severe salt treatment. Our results are in agreement with the study which reported reduction of anthocyanin content in salttreated strawberry plants [42]. According to the PCA grouping in this experiment, it is suggested that PEN could affect MDA, $\mathrm{H}_{2} \mathrm{O}_{2}$, flavonoid, anthocyanin, and proline contents mostly in $200 \mathrm{mM}$ $\mathrm{NaCl}$ treated plants [43-46]. Further, PEN effects on FW, DW, height, SOD, POX, and CAT was most pronounced in unstressed plants. It sounds that effects of PEN in sesame is most pronounced in higher $\mathrm{NaCl}$ concentrations especially, under $200 \mathrm{mM} \mathrm{NaCl}$ treatment $[47,48]$ (Figure 4).

\section{Conclusion}

Taken together, our data revealed that PEN helps sesame plants to cope with saline conditions. This is supported by the regulation of compatible solutes, as well as the increase of some antioxidant compounds observed in such conditions. In addition, the results indicated that PEN reduces the negative effects of salt stress with evidence of less membrane damage. In summary, due to the availability, PEN can be considered as a foliar application to ameliorate salinity effects in sesame.

\section{References}

1. Cardoso P, Freitas R, Figueira E (2015) Salt tolerance of rhizobial populations from contrasting environmental conditions: understanding the implications of climate change. Ecotoxicology 24(1): 143-152.

2. Aftab T, Khan MMA, da Silva JAT, Idrees M, Naeem M (2011) Role of salicylic acid in promoting salt stress tolerance and enhanced artemisinin production in Artemisia annua L. Journal of Plant Growth Regulation 30(4): 425-435.

3. Zheng J, Ma X, Zhang X, Hu Q Qian R (2018) Salicylic acid promotes plant growth and salt-related gene expression in Dianthus superbus L. (Caryophyllaceae) grown under different salt stress conditions. Physiol Mol Biol Plants 24(2): 231-238.

4. Bahrami H, Razmjoo J (2012) Effect of salinity stress ( $\mathrm{NaCl}$ ) on germination and early seedling growth of ten sesame cultivars (Sesamum indicum L.). International Journal of Agri Science 2(6): 529-537.

5. Gehlot HS, Purohit A, Shekhawat NS (2005) Metabolic changes and protein patterns associated with adaptation to salinity in Sesamum indicum cultivars. Journal of Cell and Molecular Biology 4(1): 31-39.
6. Shaki F, Ebrahimzadeh Maboud H, Niknam V (2017) Central role of salicylic acid in resistance of safflower (Carthamus tinctorius L.) against salinity. Journal of Plant Interactions 12(1): 414-420.

7. Rasheed R, Wahid A, Ashraf M, Basra SM (2010) Role of proline and glycine betaine in improving chilling stress tolerance in sugarcane buds at sprouting. International Journal of Agriculture \& Biology 12(1): 1-8.

8. Dhanapackiam S, Ilyas MM (2010) Effect of salinity on chlorophyll and carbohydrate contents of Sesbania grandiflora seedlings. Indian Journal of Science and Technology 3(1): 64-66.

9. Hassanpour H, Khavari Nejad RA, Niknam V, Najafi F, Razavi K (2013) Penconazole induced changes in photosynthesis, ion acquisition and protein profile of Mentha pulegium L. under drought stress. Physiol Mol Biol Plants 19(4): 489-498.

10. Merati MJ, Hassanpour H, Niknam V, Mirmasoumi M (2014) Exogenous application of penconazole regulates plant growth and antioxidative responses in salt stressed Mentha pulegium L. Journal of Plant Interactions 9(1): 791-801.

11. Kováčik J, Bačkor M (2007) Changes of phenolic metabolism and oxidative status in nitrogen deficient Matricaria chamomilla plants. Plant and Soil 297(1-2): 255-265.

12. Dkhil BB, Denden M (2012) Effect of salt stress on growth, anthocyanins, membrane permeability and chlorophyll fluorescence of Okra (Abelmoschus esculentus L.) seedlings. American Journal of Plant Physiology 7(4): 174-183.

13. Chutipaijit S, Cha Um S, Sompornpailin K (2009) Differential accumulations of proline and flavonoids in indica rice varieties against salinity. Pak J Bot 41(5): 2497-2506.

14. Shaki F, Maboud HE, Niknam V (2018) Penconazole alleviates saltinduced damage in safflower (Carthamus tinctorius L.) plants. Journal of Plant Interactions 13(1): 420-427.

15. Hoagland DR, Arnon DI (1950) The water-culture method for growing plants without soil. Circular. California Agricultural Experiment Station. $347\left(2^{\text {nd }} e d n\right):$ p. 32.

16. Weatherley P (1950) Studies in the water relations of the cotton plant: I. The field measurement of water deficits in leaves. New Phytologist 49(1): 81-97.

17. Bates L, Waldren R, Teare I (1973) Rapid determination of free proline for water-stress studies. Plant and Soil 39(1): 205-207.

18. Dubois M (1956) Calorimetric method for determination of sugars and related substances. Analytical Chemistry 28(3): 350-356.

19. Heath RL, Packer L (1968) Photoperoxidation in isolated chloroplasts: I. Kinetics and stoichiometry of fatty acid peroxidation. Archives of Biochemistry and Biophysics 125(1): 189-198.

20. Velikova V, Yordanov I, Edreva A (2000) Oxidative stress and some antioxidant systems in acid rain-treated bean plants: protective role of exogenous polyamines. Plant Science 151(1): 59-66.

21. Bradford MM (1976) A rapid and sensitive method for the quantitation of microgram quantities of protein utilizing the principle of protein-dye binding. Analytical Biochemistry 72(1-2): 248-254.

22. Giannopolitis CN, Ries SK (1977) Superoxide dismutases I. Occurrence in higher plants. Plant Physiol 59(2): 309-314.

23. Aebi H (1984) Catalase in vitro. Methods Enzymol 105: 121-126.

24. Abeles FB, Biles CL (1991) Characterization of peroxidases in lignifying peach fruit endocarp. Plant Physiol 95(1): 269-273.

25. Raymond J, Rakariyatham N, Azanza JL (1993) Purification and some properties of polyphenoloxidase from sunflower seeds. Phytochemistry 34(4): 927-931.

26. Pourmorad F, Hosseinimehr S, Shahabimajd N (2006) Antioxidant activity, phenol and flavonoid contents of some selected Iranian medicinal plants. African Journal of Biotechnology 5(11): 1142-1145. 
27. Wagner GJ (1979) Content and vacuole/extravacuole distribution of neutral sugars, free amino acids, and anthocyanin in protoplasts. Plant Physiol 64(1): 88-93.

28. Jaleel CA, Gopi R, Manivannan P, Panneerselvam R (2007) Responses of antioxidant defense system of Catharanthus roseus (L.) G. Don. to paclobutrazol treatment under salinity. Acta Physiologiae Plantarum 29(3): 205-209.

29. Jaleel CA, Gopi R, Kishorekumar A, Manivannan P, Sankar B, Panneerselvam R (2008) Interactive effects of triadimefon and salt stress on antioxidative status and ajmalicine accumulation in Catharanthus roseus. Acta Physiologiae Plantarum 30(3): 287-292.

30. Banu MNA, Hoque MA, Sugimoto MW, Matsuoka K, Nakamura Y, et al. (2009) Proline and glycine betaine induce antioxidant defense gene expression and suppress cell death in cultured tobacco cells under salt stress. J Plant Physiol 166(2): 146-156.

31. Ashraf M, Foolad M (2007) Roles of glycine betaine and proline in improving plant abiotic stress resistance. Environmental and Experimental Botany 59(2): 206-216.

32. Ünyayar S, KelepY, Ünal E (2004) Proline and ABA levels in two sunflower genotypes subjected to water stress. Bulg J Plant Physiol 30(3-4): 34-47.

33. Khatkar D, Kuhad M (2000) Short-term salinity induced changes in two wheat cultivars at different growth stages. Biologia Plantarum 43(4): 629-632.

34. Parida AK, Das AB (2005) Salt tolerance and salinity effects on plants: a review. Ecotoxicol Environ Saf 60(3): 324-349.

35. Hassanpour H, Nejad RAK, Niknam V, Najafi F, Razavi K (2012) Effects of penconazole and water deficit stress on physiological and antioxidative responses in pennyroyal (Mentha pulegium L.). Acta Physiologiae Plantarum 34(4): 1537-1549.

36. Cavalcanti FR, Oliveira JTA, Martins Miranda AS, Viégas RA, Silveira JAG (2004) Superoxide dismutase, catalase and peroxidase activities do not confer protection against oxidative damage in salt-stressed cowpea leaves. New Phytologist 163(3): 563-571.

37. Mittova V, Guy M, Tal M, Volokita M (2004) Salinity up-regulates the antioxidative system in root mitochondria and peroxisomes of the wild salt-tolerant tomato species Lycopersicon pennellii. J Exp Bot 55(399): 1105-1113.
38. Pan Y, Wu LJ, Yu ZL (2006) Effect of salt and drought stress on antioxidant enzymes activities and SOD isoenzymes of liquorice (Glycyrrhiza uralensis Fisch). Plant Growth Regulation 49(2-3): 157-165.

39. de Azevedo Neto AD, Prisco JT, Enéas Filho J, de Abreu CEB, Gomes Filho E (2006) Effect of salt stress on antioxidative enzymes and lipid peroxidation in leaves and roots of salt-tolerant and salt-sensitive maize genotypes. Environmental and Experimental Botany 56(1): 87-94.

40. Manivannan P, Jaleel CA, Kishorekumar A, Sankar B, Somasundaram R, et al. (2007) Changes in antioxidant metabolism of Vigna unguiculata (L.) Walp. by propiconazole under water deficit stress. Colloids Surf B: Biointerfaces 57(1): 69-74.

41. Samanta A, Das G, Das SK (2011) Roles of flavonoids in plants. carbon 100: 6 .

42. Keutgen AJ, Pawelzik E (2007) Modifications of strawberry fruit antioxidant pools and fruit quality under $\mathrm{NaCl}$ stress. Journal of Agricultural and Food Chemistry 55(10): 4066-4072.

43. Ali GM, Yasumoto S, Seki Katsuta M (2007) Assessment of genetic diversity in sesame (Sesamum indicum L.) detected by amplified fragment length polymorphism markers. Electronic Journal of Biotechnology 10(1): 12-23.

44. Kim JS, Lee BH, Kim SH, Oh KH, Cho KY (2006) Responses to environmental and chemical signals for anthocyanin biosynthesis in non-chlorophyllous corn (Zea mays L.) leaf. Journal of Plant Biology 49(1): 16-25.

45. Palma F, Lluch C, Iribarne C, García Garrido JM, García NAT (2009) Combined effect of salicylic acid and salinity on some antioxidant activities, oxidative stress and metabolite accumulation in Phaseolus vulgaris. Plant Growth Regulation 58(3): 307-316.

46. Patade VY, Bhargava S, Suprasanna P (2011) Salt and drought tolerance of sugarcane under iso-osmotic salt and water stress: growth, osmolytes accumulation, and antioxidant defense. Journal of Plant Interactions 6(4): 275-282.

47. Sairam R, Srivastava G, Saxena D (2000) Increased antioxidant activity under elevated temperatures: a mechanism of heat stress tolerance in wheat genotypes. Biologia Plantarum 43(2): 245-251.

48. Xu J, Duan X, Yang J, Beeching JR, Zhang P (2013) Coupled expression of $\mathrm{Cu} / \mathrm{Zn}$-superoxide dismutase and catalase in cassava improves tolerance against cold and drought stresses. Plant Signal Behav 8(6): e24525. 